\title{
E-Mentoring in Higher Education: A Structured Literature Review and Implications for Future Research
}

\author{
Harold Tinoco-Giraldo ${ }^{1, *} *$, Eva María Torrecilla Sánchez ${ }^{2} \mathbb{B}$ and \\ Francisco José García-Peñalvo ${ }^{3}$ (D) \\ 1 Programme in Education in the Knowledge Society, Universidad de Salamanca, 37008 Salamanca, Spain \\ 2 Research and Diagnostic Methods in Education, Faculty of Education, University of Salamanca, \\ 37008 Salamanca, Spain; emt@usal.es \\ 3 Department of Computer Science and Automation, Faculty of Science, University of Salamanca, \\ 37008 Salamanca, Spain; fgarcia@usal.es \\ * Correspondence: htinocogiraldo@usal.es; Tel.: +1-832-703-2836
}

Received: 6 May 2020; Accepted: 24 May 2020; Published: 26 May 2020

check for updates

\begin{abstract}
Mentoring in higher education helps learners acclimate to a new academic topic, increases the likelihood of academic success, and reduces attrition. Learners rely on the expertise and experience of mentors to help them graduate in a timely manner and advance on to their career. As online and distance education becomes more pervasive, computer-mediated mentoring allows learners to connect with their mentors in new ways. Research about mentoring in higher education includes investigations into the efficacy of virtual or e-mentoring. We conducted a literature review of research from 2009 to 2019 to identify relevant elements for implementing e-mentoring programs in higher education. Our research revealed that there is a consistent interest in the subject matter within educational research; however, there is a gap on virtual mentoring in higher education for students conducting offsite internships. Our research reviews e-mentoring programs, identifies how these programs are evaluated, identifies factors of successful programs, and establishes a research agenda in areas of e-mentoring programs for students in offsite internships and how they can be structured to achieve the same level of success.
\end{abstract}

Keywords: open educational resources; e-mentoring; higher education; literature review; mapping; sustainable education

\section{Introduction}

Per the United Nations Educational, Scientific, and Cultural Organization (UNESCO) Guidelines on Intercultural Education [1], higher education is the last phase of the academic learning process. The preparation obtained from higher education is either professional or academic and falls into one of four categories: technical, focusing on providing immediate solutions to social needs and demands related to the production, distribution, and use of goods and services; undergraduate, resulting in a university degree; graduate, resulting in a higher-level university degree obtained after undergraduate work, which further develops knowledge and deepens the theory learned in a specific field; and doctorate, where a student obtains tools to exercise as a researcher of a specific area.

Mentoring can help students overcome difficulties in mastering several subjects in higher education while reducing failure rates and lowering dropout rates. Mentees received personalized direction to improve attitudes, values, and skills needed to master the curriculum and develop self-confidence in their subject matter. When mentoring is developed and managed through virtual learning environments, it is recognized as e-mentoring [2-5]. 
According to Stewart and Carpenter and Neely et al. [3,5], adopting information and communication technologies creates opportunities to minimize the physical and psychological distance between people in mentoring programs Crisp [6] suggests that obstacles caused by spatial-temporal limitations are the major obstacles of traditional mentoring programs. Academic institutions have taken advantage of computer-mediated communication to provide $24 / 7$ access for mentoring. In particular, teacher to student and student to peer e-mentoring has grown in popularity in higher education over the last decade [7-9] with social media, mobile messaging, and virtual communications serving as major routes of communication [10].

Crisp [6] recognizes the potential of mentoring, although not without challenges, as a guidance strategy in higher education. Other researchers emphasize the importance of e-mentoring as a strategy to improve academic performance and to establish a tool to evaluate not only knowledge but also research and investigation capacity, critical thinking, logical-argumentative reasoning, and several basic competences needed by modern learners [11,12]. Likewise, mentoring improves learning processes and study skills $[13,14]$. Many of these studies have demonstrated that e-mentoring programs in higher education have been specifically designed to facilitate access by vulnerable populations, including minority groups $[15,16]$.

While mentoring is often recognized as important, implementing a mentoring program poses a number of challenges. UNESCO [1] prepared an information technology framework with skills that mentors need in order to integrate information and communication technologies into their social and experiential learning practices. Our project intersects information and communication technology literacy, deepening knowledge and knowledge generation approaches to reform education, encouraging a global and interdisciplinary approach to a student's future professional development, and employing mentoring to reflect and build practical knowledge $[17,18]$.

This project integrates knowledge of classroom technologies and internship methods with mentoring tools to improve organizational and management competences in the classroom and online environment [17]. Mentors will need to be able to create networked environments for students to store, share, and develop their practicums in a collaborative manner. Teachers will also need to learn to use technologies with flexible, student-centered teaching and learning strategies [19]. E-mentoring programs can be intrinsically linked to the curriculum with technology facilitating constructive learning processes between teachers and students.

A review of the e-mentoring literature reveals several types of mentoring relationships-formal/ informal, planned/spontaneous, and long-term/short-term [20]—as well as different stages of mentoring - preparation, negotiation, growth enablement, and closure [21]. However, little is known about the efficacy of e-mentoring programs that focus on learners in offsite internships and the characteristics which make them effective [19]. Recently, [14] piloted an e-mentoring program for students in offsite internships with students who graduated serving as mentors to support the development of professional competencies for those currently enrolled in a program. The success of the pilot program was attributed to carefully matching students with mentors with industry experience who share similar career goals with their mentees.

The purpose of this article is to review the factors of e-mentoring programs found in the literature and to identify how these programs are evaluated, thereby identifying factors of successful programs. Furthermore, this article establishes a research agenda in areas of e-mentoring programs for students in offsite internships and how they can be structured to achieve the same level of success.

\section{Method}

Vidal Ledo et al. [22] and Ramírez-Montoya and García-Peñalvo [23] describe a systematic literature review (SLR) as a methodological system that permits the mining of the most relevant information from the existing literature in a given field that complements pre-specified eligibility criteria, answers research questions, and is conducted through evaluation phases. 
This research uses SLR to collect and synthesize scientific evidence on e-mentoring using clearly defined research questions and to ensure that biases and limitations are kept to a minimum. The search and inclusion criteria follow a rigorous and systematic search of the literature review and analysis outlined by García-Peñalvo [24]. First, we defined the research questions and the inclusion criteria; second, we proceeded to search for and select the relevant studies; and third, we analyzed and interpreted the results. In this case, two different sets of questions were formulated for mapping and SLR.

\subsection{Research Questions}

We identified four global questions to establish the status and evolution of research related to e-mentoring in higher education. To establish relationship between the mapping questions and the research questions, we detected, obtained, and consulted the bibliography and extracted relevant information that concerns our research problem. Consequently, the following mapping questions (MQ) were formulated:

- MQ1. What has been the evolution of the number of research articles in e-mentoring in higher education since 2009?

- MQ2. Who are the prominent authors in e-mentoring in higher education?

- MQ3. What media are most frequently used to publish the results of research in e-mentoring programs in higher education?

- MQ4. Which data analysis method is used most frequently e-mentoring programs in higher education?

We developed the following research questions to conduct a more in-depth analysis of the articles:

- RQ1. What areas are being developed with the application of an e-mentoring program in higher education?

- RQ2. What are the characteristics of e-mentoring programs in higher education?

- RQ3. How are e-mentoring programs in higher education evaluated?

- RQ4. What are the indicators of effectiveness of e-mentoring programs in higher education?

\subsection{Selection Criteria}

Based on the research questions, we established criteria for the article selection process (Table 1). Once the questions and the scope of the review were defined, we established a set of six inclusion and five exclusion criteria to identify research that is relevant to answering our research questions.

Table 1. Inclusion and exclusion criteria. Source: created by the authors.

\begin{tabular}{l}
\hline \multicolumn{1}{c}{ Inclusion criteria } \\
\hline IC1. Related to e-mentoring programs applied in higher education. \\
IC2. Includes concrete and verifiable empirical research. \\
IC3. Published after a peer review process. \\
IC4. Written in English. \\
IC5. Published in high-quality (and/or impact factor) journals. \\
IC6. Research papers with quantitative, qualitative and mixed methods approaches applied. \\
\hline \multicolumn{1}{c}{ Exclusion criteria } \\
\hline EC1. Not related to specific e-mentoring programs in higher education. \\
EC2. Do not include concrete and verifiable empirical research. \\
EC3. Did not undergo a peer review process. \\
EC4. We're not published in high-quality (and/or impact factor) journals. \\
EC5. Did not use quantitative, qualitative, or mixed methods approaches. \\
\hline
\end{tabular}


Finally, we developed seven quality criteria that exceeded the inclusion and exclusion criteria (Table 2$)$ with three answer options: Yes ( 1 point), Partial ( 0.5 point), and No ( 0 point). The scoring criteria accurately interprets evidence found in each document, recognizing the answer of the 7 points as the higher score which confirms the quality reasons, evaluate an allotted score of points earned and justifies key. The cut-off point for the selection of publications was set at 6 points; all articles with a score below the cut-off point were excluded from the final selection.

Table 2. Quality criteria. Source: created by the authors.

\begin{tabular}{ll}
\hline & \multicolumn{1}{c}{ Questions } \\
\hline 1. & Did the research paper included clear objectives of research in e-mentoring? \\
2. & Did the research paper meet those objectives? \\
3. Is the study population clearly described? Is its size sufficient to perform the proposed analyzes? & Does the sample adequately represent the population represented? \\
4. & Do the authors discuss the problems and limitations of their research? \\
5. & Are the conclusions accurate and based on the results? \\
6. & Can the findings/conclusions be generalized from sample to the population? \\
7. & Are the research questions answered adequately? \\
\hline
\end{tabular}

\subsection{Search Approach}

Once we defined the selection criteria of the articles, we established the following requirements for selecting the databases:

- Are these databases relevant in this field of research and only provide quality research articles?

- Do these databases allow for similar or equal search strings and logical expressions to perform the search process?

- Are these databases accessible by the institution where the review is carried out or by the associations of which the authors are members?

- Do the databases allow searches to be conducted across the entire article or just in specific fields?

- Are the databases relevant and include only proven quality articles and documents?

Based on these requirements, we selected Scopus and Web of Science (WoS) for the SLR. The search approach for the location of the studies was defined by consensus. The descriptor "e-mentoring" did not appear in the higher education thesaurus as a single word, so we used the UNESCO Thesaurus study parameters of the Educational Sciences with the most significant descriptor being "mentoring", adding the "virtual" as part of the concept for the purpose of this work (Table 3).

Table 3. Synonyms used for lecture resources. Source: created by the authors.

\begin{tabular}{lll}
\hline $\begin{array}{c}\text { Descriptor for Studies } \\
\text { of Educational Sciences }\end{array}$ & \multicolumn{1}{c}{ Descriptor definition } & \multicolumn{1}{c}{ Synonyms } \\
\hline E-Mentoring [25] & $\begin{array}{l}\text { Mentoring using a computer-mediated } \\
\text { relationship between a more skilled } \\
\text { individual who is the mentor, and a lesser } \\
\text { skilled individual who is the mentee. }\end{array}$ & $\begin{array}{l}\text { Virtual mentoring, online mentoring, } \\
\text { electronic mentoring, distance mentoring, } \\
\text { mentoring on the internet, mentoring } \\
\text { through the internet, Telementoring, } \\
\text { internet mentoring, cybermentoring, } \\
\text { virtual tutoring, online tutoring. }\end{array}$ \\
\hline Higher education [26] & $\begin{array}{l}\text { It is taught at universities, colleges or } \\
\text { technical training academies. The teaching } \\
\text { offered by higher education is at the } \\
\text { professional level. }\end{array}$ & $\begin{array}{l}\text { University, college, graduate school, } \\
\text { tertiary school. }\end{array}$ \\
\hline Internship [27] & $\begin{array}{l}\text { It is a training experience that allows } \\
\text { students to apply and test the knowledge } \\
\text { they have acquired during their career, as } \\
\text { well as to develop the skills necessary to } \\
\text { succeed in the professional world. }\end{array}$ & Practicum, apprenticeship. \\
\hline
\end{tabular}




\subsection{Search Strings Used}

We constructed the search strings from the search terms, and we used the Boolean operators (AND/AND, OR) to connect different descriptors. In addition, we used the wildcard $\left(^{*}\right)$ in WoS [28] to account for plural terminology. The research strings used in the search engines were formulated from the research questions and the inclusion criteria. We created three combinations search strings to alleviate the way each search engine behaves (Table 4). We restricted our results to peer-reviewed documents published between 2009 and 2019, including for articles, book chapters, and conference papers. In relation to areas of interest or categories, restrictions have not been applied.

Table 4. String combinations. Source: created by the authors.

\begin{tabular}{|c|c|}
\hline Source & Research Terms \\
\hline \multirow{3}{*}{ SCOPUS } & $\begin{array}{l}\text { Combination } 1 \\
\text { TITLE-ABS-KEY (“ e-mentoring " AND “ program " AND “ highereducation") }\end{array}$ \\
\hline & $\begin{array}{l}\text { Combination } 2 \\
\text { TITLE-ABS-KEY (“ e-mentoring " AND “program " AND “ university ") }\end{array}$ \\
\hline & $\begin{array}{l}\text { Combination } 3 \\
\text { TITLE-ABS-KEY ("e-mentoring" OR "virtual mentoring" OR "online mentoring") AND ("higher } \\
\text { education" OR "university") AND ("program") AND ("internship" OR "practice" OR "apprenticeship") } \\
\text { AND (LIMIT TO (DOCTYPE, "cp") OR LIMIT-TO (DOCTYPE, "ar") OR LIMIT -TO (DOCTYPE, } \\
\text { "ch") OR LIMIT-TO (DOCTYPE, "re"))AND (LIMIT TO (LANGUAGE, "English")) }\end{array}$ \\
\hline \multirow{3}{*}{ WoS } & $\begin{array}{l}\text { Combination } 1 \\
\text { TOPIC: ("e-mentoring") AND TOPIC ("program*") AND TOPIC: ("higher education") }\end{array}$ \\
\hline & $\begin{array}{l}\text { Combination } 2 \\
\text { TOPIC: ("e-mentoring") AND TOPIC ("program*") AND TOPIC: ("university") }\end{array}$ \\
\hline & $\begin{array}{l}\text { Combination } 3 \\
\text { TOPIC: ("e-mentoring") OR TITLE: ("virtual mentoring") OR TITLE: ("online mentoring") AND TITLE: } \\
\text { ("higher education") OR TITLE: ("university") AND TITLE: ("program*") AND TITLE: ("internship") }\end{array}$ \\
\hline
\end{tabular}

We selected the process of data extraction after successive stages [29]. We created an Excel spreadsheet of the articles, recognizing the different stages for each process and for each database. This Excel spreadsheet contains the inclusion/exclusion quality criteria, and the research questions helped organize the information and facilitate the SLR report. The following link shows each stage of the process and contains all the information of each document.

https://docs.google.com/spreadsheets/d/18967gB3VwOaf81ZOuVMBlmltrcRltU4cnSftBgG5LVc/edit? usp=sharing.

During the first stage, we collected search results from two repositories and entered the data into the spreadsheet. Once all the documents found in the two repositories were registered and all titles and summaries of the studies were reviewed, we selected those concordant with the research topic and removed duplicate elements. We found that 156 articles were duplicates in Scopus and 25 were duplicates in WoS (Table 5).

In the second stage, we applied the inclusion/exclusion criteria by consulting the title and the summary of the publications. Out of 380 documents selected in the first stage, 121 passed through the second stage.

Finally, in the third stage, we applied the quality criteria, eliminating publications that obtained a score criteria of less than 6 points and discarding those papers that passed the phase due to the ambiguity of their title and abstract. Thirteen of the 121 articles obtained a score of six points, and 20 of those 121 articles obtained a score of 7 points and were therefore selected to answer the research questions.

We used prisma flow [30] for the selection process. Figure 1 shows the selection process in each stage and the number of documents selected and removed. 
Table 5. Total documents after duplicated articles were removed. Source: created by the authors.

\begin{tabular}{ccccc}
\hline Source & Research Terms & Filtered Results & Duplicate Results & $\begin{array}{c}\text { Results without } \\
\text { Duplicate }\end{array}$ \\
\hline \multirow{4}{*}{ SCOPUS } & Combination 1 & 121 & 0 & 121 \\
& Combination 2 & 137 & 112 & 25 \\
& Combination 3 & 100 & 44 & 56 \\
\cline { 2 - 5 } & Total & 358 & 156 & 202 \\
\hline \multirow{3}{*}{ WoS } & Combination 1 & 14 & 0 & 14 \\
& Combination 2 & 20 & 7 & 13 \\
& Combination 3 & 211 & 18 & 193 \\
\cline { 2 - 5 } & Total & 245 & 25 & 220 \\
\hline \multirow{2}{*}{ Total documents } & 603 & 181 & 422 \\
\hline
\end{tabular}

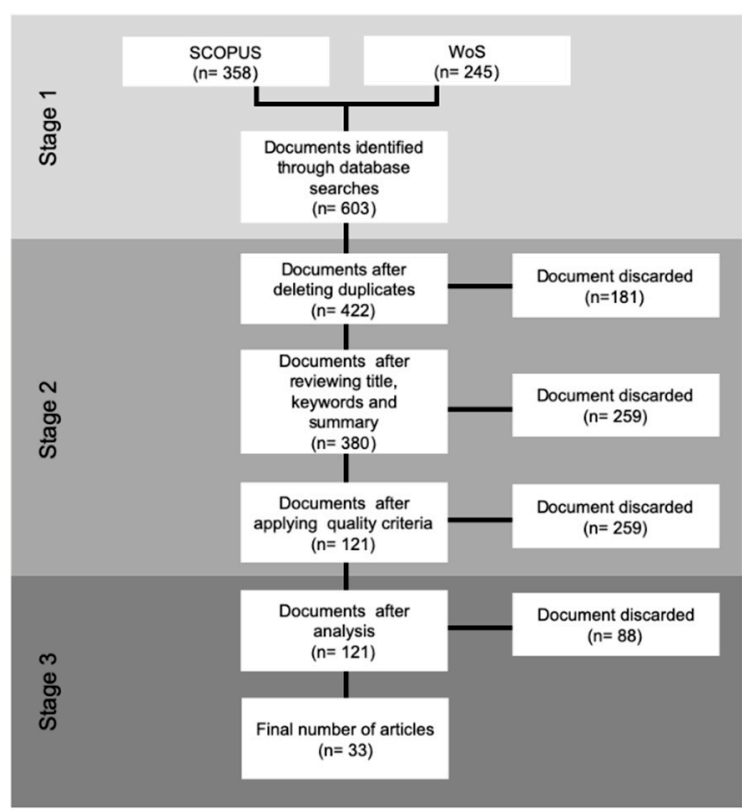

Figure 1. Selection process. Source: created by the authors.

\section{Results}

We analyzed 33 articles (Table 6) to answer the research questions. To this end, the section is structured according to the questions posed, first presenting the results of the mapping and then those of the SLR.

Table 6. Results of the review of the selected articles final stage. Source: created by the authors.

\begin{tabular}{lccl}
\hline \multicolumn{1}{c}{ Author } & Year & Publication Type & \multicolumn{1}{c}{ Subject } \\
\hline $\begin{array}{l}\text { Stewart, S., and } \\
\text { Carpenter, C. }\end{array}$ & 2009 & Article & $\begin{array}{l}\text { Describes the implementation and evaluation of a } \\
\text { pilot e-mentoring program to address the need for } \\
\text { support of physical therapists working in rural } \\
\text { positions in British Colombia, Canada. }\end{array}$ \\
\hline $\begin{array}{l}\text { Rodrigues Reali, A., } \\
\begin{array}{l}\text { Simões Tancredi R., } \\
\text { and Nicoletti } \\
\text { Mizukami, M. }\end{array}\end{array}$ & 2010 & Book Chapter & $\begin{array}{l}\text { Analyzes the development phases of the Online } \\
\text { Mentoring Program (OMP) from the Federal } \\
\text { University of São Carlos, Brazil. }\end{array}$ \\
\hline $\begin{array}{l}\text { DiRenzo M.S., } \\
\text { Linnehan F., Shao P., } \\
\text { and Rosenberg W.L. }\end{array}$ & 2010 & Article & $\begin{array}{l}\text { Model of electronic mentoring (e-mentoring) from } \\
\text { Drexel University, USA. }\end{array}$ \\
\hline
\end{tabular}


Table 6. Cont.

\begin{tabular}{|c|c|c|c|}
\hline Author & Year & Publication Type & Subject \\
\hline Venis L. & 2010 & Book Chapter & $\begin{array}{l}\text { Individualized feedback and e-mentoring program } \\
\text { from UCLA Extension, USA. }\end{array}$ \\
\hline Murphy, W. M. & 2011 & Article & $\begin{array}{l}\text { Explores e-mentoring in the context of student } \\
\text { development as a tool for increasing mentees' } \\
\text { propensity to initiate developmental relationships } \\
\text { from Northern Illinois University, USA. }\end{array}$ \\
\hline $\begin{array}{l}\text { Obura T., Brant W.E., } \\
\text { Miller F., and } \\
\text { Parboosingh I.J. }\end{array}$ & 2011 & Article & $\begin{array}{l}\text { Analyses information about an e-mentoring pilot } \\
\text { was offered to } 10 \text { Radiology residents in the Aga } \\
\text { Khan University Postgraduate Medical Education } \\
\text { Program. Kenya. }\end{array}$ \\
\hline Golubski, P.M. & 2011 & Book Chapter & $\begin{array}{l}\text { E-mentoring initiative conducted through virtual } \\
\text { and Web 2.0. at Carnegie Mellon University, USA }\end{array}$ \\
\hline $\begin{array}{l}\text { Williams, S. L., and } \\
\text { Kim, J. }\end{array}$ & 2011 & Article & $\begin{array}{l}\text { Explains the structure and process of an } \\
\text { e-mentoring system designed for an online Master's } \\
\text { degree at Illinois University, Carnegie Mellon, USA. }\end{array}$ \\
\hline $\begin{array}{l}\text { Risquez, A., and } \\
\text { Sánchez-García, M }\end{array}$ & 2012 & Article & $\begin{array}{l}\text { Investigates how emotionally peer electronic } \\
\text { mentoring program was implemented at } \\
\text { Universidad Nacional de Educación a Distancia, } \\
\text { Spain }\end{array}$ \\
\hline $\begin{array}{l}\text { Green, M.G., Niemi } \\
\text { A.D., and } \\
\text { Roudkovski, M. }\end{array}$ & 2012 & Conference Paper & $\begin{array}{l}\text { Details the logistics and challenges of starting up an } \\
\text { e-mentoring program created to contribute with } \\
\text { students' experiences at LeTourneau } \\
\text { University, USA. }\end{array}$ \\
\hline $\begin{array}{l}\text { Gunawardena, C., } \\
\text { Jayatilleke, B., } \\
\text { Fernando, S., } \\
\text { Kulasekere, C., } \\
\text { Lamontagne, M., } \\
\text { Ekanayake, M., and } \\
\text { Thaiyamuthu, T }\end{array}$ & 2012 & Conference Paper & $\begin{array}{l}\text { Results of a e- tutor mentor program based on } \\
\text { WisCom model using Moodle platform at } \\
\text { University of Colombo School of Computing } \\
\text { (UCSC), Sir Lanka. }\end{array}$ \\
\hline $\begin{array}{l}\text { Butler, A. J., } \\
\text { Whiteman, R. S., } \\
\text { and Crow, G. M }\end{array}$ & 2013 & Article & $\begin{array}{l}\text { Discusses the pros and inconveniencies of } \\
\text { e-mentoring programs in the education field at the } \\
\text { University of Wisconsin, USA. }\end{array}$ \\
\hline $\begin{array}{l}\text { De Janasz, S., and } \\
\text { Godshalk, V. M }\end{array}$ & 2013 & Article & $\begin{array}{l}\text { Examine the import of a e-mentoring program at } \\
\text { Pennsylvania University, USA, recognizing the } \\
\text { inputs of mentoring relationships and } \\
\text { learning satisfaction. }\end{array}$ \\
\hline $\begin{array}{l}\text { Greindl, T., Schirner, } \\
\text { S., and Albert } \\
\text { Ziegler, H. S. }\end{array}$ & 2013 & Conference Paper & $\begin{array}{l}\text { Recognizes the activities and contents related to } \\
\text { CyberMentor e-mentoring program developed to } \\
\text { measure the STEM characteristics of girls at the } \\
\text { University of Regensburg, Germany. }\end{array}$ \\
\hline $\begin{array}{l}\text { Khan, R., and } \\
\text { Gogos, A. }\end{array}$ & 2013 & Article & $\begin{array}{l}\text { Implementation or a e-mentoring program at } \\
\text { Maryland University, USA, that help master's } \\
\text { students in biotechnology to increase and master } \\
\text { synergistic processes in the area of knowledge. }\end{array}$ \\
\hline $\begin{array}{l}\text { Nuankaew P., and } \\
\text { Temdee, P. }\end{array}$ & 2014 & Conference Paper & $\begin{array}{l}\text { Proposes specific features for an online mentoring } \\
\text { program. The study was applied to } 588 \text { students of } \\
\text { the Faculty of Information and Technology of } \\
\text { Rajabhat Maha Sarakham University, Thailand. }\end{array}$ \\
\hline $\begin{array}{l}\text { Jacobs, K., Doyle, N., } \\
\text { and Ryan, C. }\end{array}$ & 2015 & Article & $\begin{array}{l}\text { Investigates the perception and impact of the } \\
\text { e-mentoring experiences of } 29 \text { graduate students } \\
\text { from an online post-doctoral program in } \\
\text { Occupational Therapy at Boston University, USA. }\end{array}$ \\
\hline
\end{tabular}


Table 6. Cont.

\begin{tabular}{lccl}
\hline \multicolumn{1}{c}{ Author } & Year & Publication Type & \multicolumn{1}{c}{ Subject } \\
\hline $\begin{array}{l}\text { Nuankaew, P., and } \\
\text { Temdee, P. }\end{array}$ & 2015 & Article & $\begin{array}{l}\text { Recognizes the different elements that are } \\
\text { compatible for an e-mentoring program, based on } \\
\text { the assumption that the mentor and the mentee can } \\
\text { work successfully not only on some common } \\
\text { attributes between them, but also on some different } \\
\end{array}$ \\
& & $\begin{array}{l}\text { attributes that are compatible between them. } \\
\text { The study of the Program was done with Mae Fah }\end{array}$ \\
& Luang University, Phayao University, Chiang Rai \\
& Rajabhat University and Rajabhat Maha Sarakham \\
& University, Thailand.
\end{tabular}

\begin{tabular}{|c|c|c|c|}
\hline $\begin{array}{l}\text { Drouin, M., Stewart, } \\
\text { J., and Van } \\
\text { Gorder, K. }\end{array}$ & 2015 & Article & $\begin{array}{l}\text { Using mixed methods, the article examines the } \\
\text { effectiveness of an e-mentoring program designed } \\
\text { to logistically support students with their } \\
\text { professors, in order to increase success rates in } \\
\text { virtual programs at the university of Indiana and } \\
\text { Purdue University, USA. }\end{array}$ \\
\hline
\end{tabular}

\begin{tabular}{|c|c|c|c|}
\hline $\begin{array}{l}\text { Ligadu, C., and } \\
\text { Anthony, P. }\end{array}$ & 2015 & Article & $\begin{array}{l}\text { MentorTokou is an e-mentoring tool that has been } \\
\text { developed to encourage and provide mentoring to } \\
\text { the students of psychology and education programs } \\
\text { at the University of Sabah, Malaysia. }\end{array}$ \\
\hline
\end{tabular}

\begin{tabular}{|c|c|c|c|}
\hline Owen, H.D. & 2015 & Article & $\begin{array}{l}\text { Outline a virtual learning and professional } \\
\text { development program offered at Te Wānanga O } \\
\text { Aotearoa college for indigenous people, New } \\
\text { Zealand, recognizing the benefits of Communities } \\
\text { of Practice (CoP) online as successful platforms to } \\
\text { provide mentoring. }\end{array}$ \\
\hline
\end{tabular}

\begin{tabular}{|c|c|c|c|}
\hline $\begin{array}{l}\text { Kahraman, M., and } \\
\text { Abdullah, K. }\end{array}$ & 2016 & Article & $\begin{array}{l}\text { Focused on supporting the professional } \\
\text { development of undergraduate students, } \\
\text { postgraduate students and graduates from the } \\
\text { department of Computer Education and } \\
\text { Instructional Technologies at Anadolu University, } \\
\text { Turkey. An e-mentoring document was developed } \\
\text { that recognized the different phases of the program } \\
\text { and displayed all the data from semi-structured } \\
\text { interviews with participants. }\end{array}$ \\
\hline
\end{tabular}

\begin{tabular}{|c|c|c|c|}
\hline $\begin{array}{l}\text { Doyle, N., Jacobs, K., } \\
\text { and Ryan, C. }\end{array}$ & 2016 & Article & $\begin{array}{l}\text { Investigates the different perspectives of } \\
\text { e-mentoring in a program designed for } \\
\text { post-professional occupational therapy students } \\
\text { from the Boston University Sargent College, USA. }\end{array}$ \\
\hline ChanLin, L. J. & 2016 & Article & $\begin{array}{l}\text { Explores the responses of students who have } \\
\text { participated in an e-mentoring program and collects } \\
\text { all the feedback and learning experiences from a } \\
\text { program established at a university in } \\
\text { northern Taiwan. }\end{array}$ \\
\hline $\begin{array}{l}\text { Trainer, E. H., } \\
\text { Kalyanasundaram, } \\
\text { A., and Herbsleb, } \\
\text { J. D }\end{array}$ & 2017 & Conference Paper & $\begin{array}{l}\text { Collects information from the FOSS virtual } \\
\text { mentoring program designed for students at } \\
\text { Carnegie Mellon University, USA, who want to } \\
\text { develop and achieve academically related job } \\
\text { opportunities. }\end{array}$ \\
\hline $\begin{array}{l}\text { Tominaga, A., and } \\
\text { Kogo, C. }\end{array}$ & 2018 & Article & $\begin{array}{l}\text { Identify the key success factors for e-mentoring and } \\
\text { recognize the impact of a virtual mentoring } \\
\text { program with students at a university in Japan. }\end{array}$ \\
\hline
\end{tabular}


Table 6. Cont.

\begin{tabular}{|c|c|c|c|}
\hline Author & Year & Publication Type & Subject \\
\hline $\begin{array}{l}\text { Tinoco-Giraldo. H., } \\
\text { Torrecilla-Sánchez. } \\
\text { E. M., and } \\
\text { García-Peñalvo. F.J. }\end{array}$ & 2018 & Conference Paper & $\begin{array}{l}\text { Offers an e-mentoring program designed for } \\
\text { students in academic practices and that can be used } \\
\text { in different educational programs. The pilot of the } \\
\text { program was carried out in a Colombian University. }\end{array}$ \\
\hline $\begin{array}{l}\text { Owen, H.D., } \\
\text { Whalley, R., } \\
\text { Dunmill, M., and } \\
\text { Eccles, H }\end{array}$ & 2018 & Article & $\begin{array}{l}\text { Presents a virtual academic mentoring program for } \\
\text { the professional development of learning, } \\
\text { recognizes the value that the participants give to the } \\
\text { program, and is directed to students of education } \\
\text { from indigenous communities at the Wānanga O } \\
\text { Aotearoa College, New Zealand. }\end{array}$ \\
\hline $\begin{array}{l}\text { Farheen, J., and } \\
\text { Dixit, S. }\end{array}$ & 2018 & Conference Paper & $\begin{array}{l}\text { Shows an application made exclusively for a virtual } \\
\text { education program that supports students at a } \\
\text { university in North India. }\end{array}$ \\
\hline $\begin{array}{l}\text { Singh P., and } \\
\text { Kumar K. }\end{array}$ & 2019 & Article & $\begin{array}{l}\text { Recognizes an effective use of virtual mentoring } \\
\text { processes and identifies key skills for } \\
\text { entrepreneurial development of participants at a } \\
\text { university in the state of Rajasthan, north-west part } \\
\text { of India. }\end{array}$ \\
\hline $\begin{array}{l}\text { Haran, V. V., and } \\
\text { Jeyaraj, A. }\end{array}$ & 2019 & Article & $\begin{array}{l}\text { Explores an e-mentoring program applied at the } \\
\text { University of Urbana-Champaign, USA, with some } \\
\text { organizational settings, emphasizing how learning } \\
\text { acts as career support in addition to psychosocial } \\
\text { and role modeling to support learning of new skills } \\
\text { and how learning increases organizational } \\
\text { engagement of mentees. }\end{array}$ \\
\hline $\begin{array}{l}\text { Doukakis, S., } \\
\text { Koutidou, E., and } \\
\text { Aspasia, } \mathrm{O}\end{array}$ & 2019 & Conference Paper & $\begin{array}{l}\text { Debate on key aspects of e-mentoring, in practical } \\
\text { and academic contexts, identifies objectives, role } \\
\text { models, and mentoring modalities to be applied in } \\
\text { Greek universities. }\end{array}$ \\
\hline Briscoe, $\mathrm{P}$. & 2019 & Article & $\begin{array}{l}\text { Assess the benefit of virtual mentoring between } \\
\text { student teacher candidates and practicing teachers } \\
\text { and recognizes the experience that mentors can offer } \\
\text { to teacher candidates. The process was developed } \\
\text { for the students of the College of Education at } \\
\text { Niagara University, USA. }\end{array}$ \\
\hline
\end{tabular}

\subsection{Mapping Results}

MQ1. What has been the evolution of the number of research articles in e-mentoring in higher education since 2009?

To answer this question, we analyzed the articles by the year they were published (Figure 2). The chart suggests that since 2011, interest in e-mentoring research has increased regardless of the decrease in the number of publications in the years 2014 and 2017. Since 2017, we observed an increased interest in new learning and knowledge management techniques, especially mentoring and coaching. Each technique oriented to the achievement of a key objective for university and college graduates and to the potential and capacity for personal development that each individual possesses [31]. 


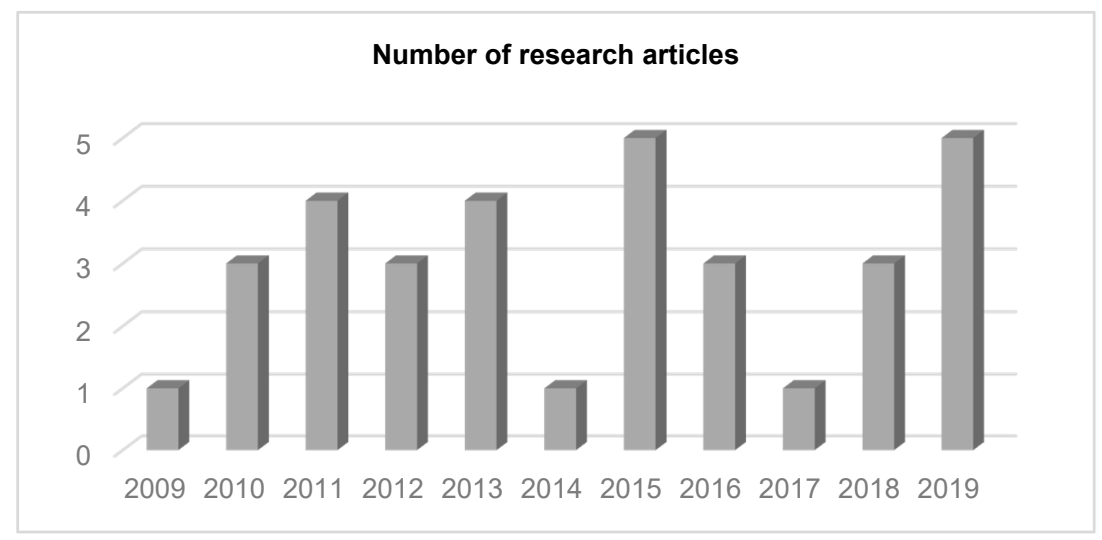

Figure 2. Number of research articles per year.

MQ2. Who are the prominent authors in the field of e-mentoring in higher education?

After reviewing the names of the authors of the research papers, we determined that the predominant authors were Nuankaew, Temdee, and Owen (Table 4). However, there were a total of 79 authors for the 33 documents (Table 7).

Table 7. Author and number of publications. Source: created by the authors.

\begin{tabular}{lc}
\hline \multicolumn{1}{c}{ Author } & $\begin{array}{c}\text { Number of } \\
\text { Publications }\end{array}$ \\
\hline Nuankaew P.; Temdee P.; Owen, H.D. & 2 \\
\hline Stewart, S.; Carpenter, C; Rodrigues Reali, A.; Simões Tancredi R; Mizukami; Nicoletti \\
Mizukami, M; DiRenzo M.S.; Linnehan F.; Shao P.; Rosenberg W; Venis, L.; Murphy, W. M.; \\
Obura T.; Brant W.E.; Miller F.; Parboosingh I.; Golubski, P.M; Williams, S. L.; Kim, J.; \\
Risquez, A; Sánchez-García, M; Green, M.G.; Niemi A.D.; Roudkovski, M.; Gunawardena, \\
C.; Jayatilleke, B.; Fernando, S.; Kulasekere, C.; Lamontagne, M.; Ekanayake, M.; \\
Thaiyamuthu, T.; Butler, A. J.; Whiteman, R. S.; Crow, G. M.; Greindl, T.; Schirner, S.; Albert \\
Ziegler, H. S.; Khan, R.; Gogos, A.; Jacobs, K.; Doyle, N.; Ryan, C.; Drouin, M.; Stewart, J.; \\
Van Gorder, K.; Ligadu, C.; Anthony, P.; Kahraman, M.; Abdullah, K.; Doyle, N.; Jacobs, K.; \\
Ryan, C.; ChanLin, L. J.; Trainer, E. H.; Kalyanasundaram, A.; Herbsleb, J. D.; Tominaga, A.; \\
Kogo, C; Tinoco-Giraldo. H.; Torrecilla-Sánchez. E. M.; García-Peñalvo. F.J; Whalley, R.; \\
Dunmill, M.; Eccles, H.; Farheen, J.; Dixit, S.; Singh P.; Kumar, K.; Haran, V. V.; Jeyaraj, A.; \\
Doukakis, S.; Koutidou, E.; Aspasia, O.; Briscoe, P. \\
\hline
\end{tabular}

MQ3. What media are most frequently used to publish the results of research in e-mentoring programs in higher education?

The vast majority of media published about e-mentoring programs in higher education were research journals (22) followed by conference papers (8) and book chapters (3) (Table 8).

Table 8. Source of publications. Source: created by the authors.

\begin{tabular}{|c|c|c|c|c|}
\hline Journal & SJR2019 & Country & Subject Area & $\mathbf{N}^{\circ}-\mathrm{P}$ \\
\hline $\begin{array}{l}\text { International Journal of Therapy } \\
\text { and Rehabilitation }\end{array}$ & 0.19 & United Kingdom & Health Professions & 1 \\
\hline Journal of Vocational Behavior & 2.16 & United States & $\begin{array}{l}\text { Business, Management } \\
\text { and Accounting }\end{array}$ & 1 \\
\hline Cadernos de Pesquisa & 0.23 & Brazil & Social Science-Education & 1 \\
\hline $\begin{array}{l}\text { Academy of Management } \\
\text { Learning and Education }\end{array}$ & 2.03 & United States & $\begin{array}{l}\text { Business, Management } \\
\text { and Accounting }\end{array}$ & 1 \\
\hline BMC Medical Education & 0.80 & United Kingdom & Medicine & 1 \\
\hline $\begin{array}{l}\text { International Journal of Evidence } \\
\text { based Coaching and Mentoring }\end{array}$ & 0.30 & United Kingdom & $\begin{array}{l}\text { Business, Management } \\
\text { and Accounting }\end{array}$ & 1 \\
\hline
\end{tabular}


Table 8. Cont.

\begin{tabular}{|c|c|c|c|c|}
\hline Journal & SJR2019 & Country & Subject Area & $\mathbf{N}^{0}-\mathrm{P}$ \\
\hline Internet and Higher Education & 3.31 & United Kingdom & Computer Science & 1 \\
\hline $\begin{array}{l}\text { International Journal of Mentoring } \\
\text { and Coaching in Education }\end{array}$ & 0.43 & United Kingdom & Social Science- Education & 2 \\
\hline $\begin{array}{l}\text { Group and Organization } \\
\text { Management }\end{array}$ & 1.77 & United States & Arts and Humanities & 1 \\
\hline $\begin{array}{l}\text { Online Learning (formerly Journal } \\
\text { of Asynchronous Learning Network) }\end{array}$ & 0.55 & United States & Computer Science & 1 \\
\hline $\begin{array}{l}\text { Occupational Therapy in } \\
\text { Health Care }\end{array}$ & 0.23 & United States & Health Professions & 1 \\
\hline Wireless Personal Communications & 0.25 & Netherlands & Computer Science & 1 \\
\hline Distance Education & 0.97 & United Kingdom & Social Science- Education & 1 \\
\hline Research in Learning Technology & 0.58 & United Kingdom & Computer Science & 1 \\
\hline $\begin{array}{l}\text { Turkish Online Journal of Distance } \\
\text { Education }\end{array}$ & 0.27 & Turkey & Social Science- Education & 1 \\
\hline $\begin{array}{l}\text { Occupational Therapy } \\
\text { International }\end{array}$ & 0.31 & Egypt & Health Professions & 1 \\
\hline $\begin{array}{l}\text { Journal of Educational Media and } \\
\text { Library Sciences }\end{array}$ & 0.26 & Taiwan & Arts and Humanities & 1 \\
\hline $\begin{array}{l}\text { Universal Journal of Educational } \\
\text { Research }\end{array}$ & 0.19 & United States & Social Science- Education & 1 \\
\hline Journal of Educators Online & 0.21 & United States & Social Science- Education & 1 \\
\hline $\begin{array}{l}\text { Academy of Entrepreneurship } \\
\text { Journal }\end{array}$ & 0.20 & United States & $\begin{array}{l}\text { Business, Management } \\
\text { and Accounting }\end{array}$ & 1 \\
\hline $\begin{array}{l}\text { Information Resources } \\
\text { Management Journal }\end{array}$ & 0.18 & United States & $\begin{array}{l}\text { Business, Management } \\
\text { and Accounting }\end{array}$ & 1 \\
\hline
\end{tabular}

Note: Number of publications ( $\left.\mathrm{N}^{\circ}-\mathrm{P}\right)$, SJR index according to SCIMAGO Institutions Ranking (Science evolution resource to assess worldwide universities and research-focused institutions).

Table 9 shows the journal's impact factor.

Table 9. Journals' impact factor.

\begin{tabular}{|c|c|c|c|c|c|c|c|c|}
\hline \multirow{2}{*}{ Journal } & \multirow{2}{*}{$\begin{array}{c}\text { Year } \\
\text { Publication }\end{array}$} & \multicolumn{4}{|c|}{ SCOPUS } & \multicolumn{3}{|c|}{ JCR } \\
\hline & & $\mathbf{Q}$ & SJR & $\begin{array}{c}\mathrm{H} \\
\text { Index }\end{array}$ & $\begin{array}{l}\text { Citescore } \\
\text { Rank }\end{array}$ & $\mathbf{Q}$ & Index & $\begin{array}{l}\text { Citescore } \\
\text { Rank }\end{array}$ \\
\hline $\begin{array}{l}\text { International Journal of } \\
\text { Therapy and Rehabilitation }\end{array}$ & 2009 & 3 & 0.205 & 21 & $13 / 65$ & & & \\
\hline Journal of Vocational Behavior & 2010 & 1 & 1.687 & 18 & $116 / 682$ & 1 & 2.604 & $17 / 63$ \\
\hline Cadernos de Pesquisa & 2010 & 3 & 0.155 & 13 & $18 / 26$ & & & \\
\hline $\begin{array}{l}\text { Academy of Management } \\
\text { Learning and Education }\end{array}$ & 2011 & 1 & 2.188 & 63 & $130 / 531$ & 1 & 1.36 & $30 / 224$ \\
\hline $\begin{array}{l}\text { BMC Medical Education } \\
\text { International Journal of }\end{array}$ & 2011 & 2 & 0.632 & 54 & $29 / 361$ & 1 & 1.66 & $1 / 206$ \\
\hline $\begin{array}{l}\text { Evidence based Coaching and } \\
\text { Mentoring }\end{array}$ & 2011 & 4 & 0.65 & 82 & $67 / 89$ & & & \\
\hline $\begin{array}{l}\text { Internet and Higher Education } \\
\text { International Journal of }\end{array}$ & 2012 & 1 & 1.997 & 75 & $29 / 434$ & 1 & 2.47 & $15 / 219$ \\
\hline $\begin{array}{l}\text { Mentoring and Coaching } \\
\text { inEducation }\end{array}$ & 2013 & 2 & 0.651 & 12 & $10 / 20$ & & & \\
\hline $\begin{array}{l}\text { Group and Organization } \\
\text { Management }\end{array}$ & 2013 & 1 & 1.313 & 74 & $18 / 223$ & 2 & 1.400 & $27 / 75$ \\
\hline $\begin{array}{l}\text { Online Learning (formerly } \\
\text { Journal of Asynchronous } \\
\text { Learning Network) }\end{array}$ & 2013 & 3 & 0.284 & 42 & $60 / 85$ & & & \\
\hline $\begin{array}{l}\text { Occupational Therapy in } \\
\text { Health Care }\end{array}$ & 2015 & 3 & 0.22 & 20 & $11 / 70$ & & & \\
\hline $\begin{array}{l}\text { Wireless Personal } \\
\text { Communications }\end{array}$ & 2015 & 2 & 0.261 & 48 & $376 / 2004$ & 4 & 0.701 & $63 / 85$ \\
\hline
\end{tabular}


Table 9. Cont.

\begin{tabular}{|c|c|c|c|c|c|c|c|c|}
\hline \multirow{2}{*}{ Journal } & \multirow{2}{*}{$\begin{array}{c}\text { Year } \\
\text { Publication }\end{array}$} & \multicolumn{4}{|c|}{ SCOPUS } & \multicolumn{3}{|c|}{ JCR } \\
\hline & & $\mathbf{Q}$ & SJR & $\begin{array}{c}\mathrm{H} \\
\text { Index }\end{array}$ & $\begin{array}{l}\text { Citescore } \\
\text { Rank }\end{array}$ & $\mathbf{Q}$ & Index & $\begin{array}{l}\text { Citescore } \\
\text { Rank }\end{array}$ \\
\hline Distance Education & 2015 & 1 & 1.43 & 40 & $18 / 263$ & 1 & 2.021 & $20 / 231$ \\
\hline $\begin{array}{l}\text { Research in Learning } \\
\text { Technology }\end{array}$ & 2015 & 1 & 1.083 & 19 & $20 / 236$ & & & \\
\hline $\begin{array}{l}\text { Turkish Online Journal of } \\
\text { Distance Education }\end{array}$ & 2016 & 3 & 0.222 & 17 & $8 / 91$ & & & \\
\hline $\begin{array}{l}\text { Occupational Therapy } \\
\text { International }\end{array}$ & 2016 & 2 & 0.293 & 32 & $4 / 53$ & 4 & 0.780 & $55 / 65$ \\
\hline $\begin{array}{l}\text { Journal of Educational Media } \\
\text { and Library Sciences }\end{array}$ & 2016 & 2 & 0.233 & 7 & $9 / 14$ & & & \\
\hline $\begin{array}{l}\text { Universal Journal of } \\
\text { Educational Research }\end{array}$ & 2018 & 3 & 0.256 & 68 & $70 / 206$ & & & \\
\hline Journal of Educators Online & 2019 & 3 & 0.21 & 13 & $4 / 39$ & & & \\
\hline $\begin{array}{l}\text { Academy of Entrepreneurship } \\
\text { Journal }\end{array}$ & 2019 & 3 & 0.20 & 9 & $3 / 49$ & & & \\
\hline $\begin{array}{l}\text { Information Resources } \\
\text { Management Journal }\end{array}$ & 2019 & 3 & 0.18 & 37 & $4 / 25$ & & & \\
\hline
\end{tabular}

Note: The Scopus and JCR indexes and Quartiles correspond to the year of publication of each article.

Table 10 shows that the most relevant research was conducted in the United States (15) followed by Malaysia (2), New Zealand (2), and India (2). Furthermore, a growing body of evidence highlights the importance of a competent mentoring process in academic research; therefore, it is important to recognize the institutions that have designed, implemented, and evaluated e-mentoring programs in these documents (Table 11).

Table 10. Conferences and books published. Source: created by the authors.

\begin{tabular}{|c|c|}
\hline Conference & Place and Year \\
\hline American Society for Engineering Education Conference & San Antonio, United States, 2012 \\
\hline $\begin{array}{l}\text { International Conference on Advances in ICT for Emerging } \\
\text { Regions (ICTer2012) }\end{array}$ & Colombo, Sir Lanka, 2012 \\
\hline IADIS International Conference Collaborative Technologies & Prague, Czech Republic, 2013 \\
\hline $\begin{array}{l}\text { 4th International Conference on Wireless Communications, Vehicular } \\
\text { Technology, Information Theory and Aerospace and Electronics } \\
\text { Systems (VITAE) }\end{array}$ & Aalborg, Denmark, 2014 \\
\hline $\begin{array}{l}\text { IEEE/ACM 39th International Conference on Software Engineering: } \\
\text { Software Engineering Education and Training Track (ICSE-SEET) }\end{array}$ & Buenos Aires, Argentina, 2017 \\
\hline $\begin{array}{l}\text { 2nd International Conference on I-SMAC (IoT in Social, Mobile, Analytics } \\
\text { and Cloud) (I-SMAC) I-SMAC (IoT in Social, Mobile, Analytics and } \\
\text { Cloud) (I-SMAC) }\end{array}$ & Palladam, India, 2018 \\
\hline $\begin{array}{l}\text { Sixth International Conference on Technological Ecosystems for } \\
\text { Enhancing Multiculturality }\end{array}$ & Salamanca, Spain, 2018 \\
\hline $\begin{array}{l}\text { 4th South-East Europe Design Automation, Computer Engineering, } \\
\text { Computer Networks and Social Media Conference (SEEDA-CECNSM) }\end{array}$ & Piraeus, Greece, 2019 \\
\hline Books & Year \\
\hline The Wiley International handbook of mentoring & 2010 \\
\hline $\begin{array}{l}\text { Cases on online tutoring, mentoring, and educational services: Practices } \\
\text { and applications }\end{array}$ & 2010 \\
\hline $\begin{array}{l}\text { Pedagogical and Andragogical teaching and learning with information } \\
\text { communication technologies }\end{array}$ & 2011 \\
\hline
\end{tabular}


Table 11. Universities where the studies were conducted and the target group of study. Source: created by the authors.

\begin{tabular}{|c|c|}
\hline University & Study Target Group \\
\hline British Columbia University, Canada & Physiotherapy students in rural positions \\
\hline Universidad Federal São Carlos, Brazil & Students of Education, aspiring teachers \\
\hline Drexel University, USA & Psychology Students \\
\hline UCLA, USA & Virtual Undergraduate Students \\
\hline Northern Illinois University, USA & Business Students \\
\hline Aga Khan University, Kenya & Graduate students in Radiology \\
\hline Carnegie Mellon University, USA & Readmitted students and first-year adults \\
\hline Illinois University Urbana-Champaign, USA & Virtual Master's Students \\
\hline Universidad Nacional de Educación a Distancia, Spain & Students of Education \\
\hline LeTourneau University, USA & First year engineering students \\
\hline Colombo University, Sir Lanka & Virtual Undergraduate Students \\
\hline Wisconsin University, USA & Students of Education \\
\hline Pennsylvania University, USA & Business Students \\
\hline Regensburg University, Germany & Female first-year engineering students \\
\hline Maryland University, USA & Master's students in Biotechnology \\
\hline Rajabhat Maha Sarakham University, Thailand & Computer and Technology Students \\
\hline Boston University, USA & Postdoctoral students in Occupational Therapy \\
\hline Mae Fah Luang University, Phayao University, Chiang Rai & \\
\hline $\begin{array}{l}\text { Rajabhat University and Rajabhat Maha Sarakham } \\
\text { University, Thailand }\end{array}$ & Computer and technology students \\
\hline Indiana University and Purdue University, USA & Students and teachers of Education \\
\hline Sabah University, Malasya & Students of Psychology and Education programs \\
\hline Te Wānanga O Aotearoa University, New Zealand & Students of Education \\
\hline Anadolu University, Turkey & $\begin{array}{l}\text { Students and graduates of Computer and } \\
\text { Technology Education }\end{array}$ \\
\hline University of Boston, Sargent College, USA & Post-Professional Occupational Therapy Students \\
\hline Catholic Fu Jen University, Taiwan & Students of Education \\
\hline Carnegie Mellon University, USA & Software Development Students \\
\hline University $X$ in Japan $X$ (no information) & University students $X$, no program information \\
\hline Universidad de Manizales, Colombia & Academic Internship Students Marketing Program \\
\hline Te Wānanga O Aotearoa University, New Zealand & Students and teachers of Education \\
\hline Technological University of Visvesvaraya, India & Engineering students \\
\hline Manipal University Jaipur, India & $\begin{array}{l}\text { Multi-faculty students with business and } \\
\text { entrepreneurial skills }\end{array}$ \\
\hline $\begin{array}{l}\text { University of Illinois Urbana-Champaign and Wright State } \\
\text { University, USA }\end{array}$ & Business Students \\
\hline $\begin{array}{l}\text { American College of Greece, Open University Hellenic, } \\
\text { Institute of Political Education of Athens, Greece }\end{array}$ & Students of Education \\
\hline Niagara University, USA & Students of Education \\
\hline
\end{tabular}

Table 12 Shows a documentary analysis of the particular differences found among conference papers, journal papers, and book chapters.

Table 12. Analysis of the particular differences found among conference papers, journal papers, and book chapters.

\begin{tabular}{|c|c|c|}
\hline Major Findings & Media & Difference on Findings \\
\hline \multirow{3}{*}{$\begin{array}{l}\text { Dimensions of } \\
\text { mentoring }\end{array}$} & Article & - $\quad$ University and college dimensions $[7-9,12,16,32]$. \\
\hline & Conference papers & $\begin{array}{ll}\text { - } & \text { Framework of e-mentoring experiences }[14,33,34] \\
\text { - } & \text { Expectations and critical analysis of mentoring }[35,36]\end{array}$ \\
\hline & Book chapters & $\begin{array}{l}\text { - Administrative dimension of mentoring [37,38] } \\
\text { - } \quad \text { Mentoring is considered to be an essential practice among the } \\
\text { functions of teachers [37] }\end{array}$ \\
\hline
\end{tabular}


Table 12. Cont.

\begin{tabular}{|c|c|c|}
\hline Major Findings & Media & Difference on Findings \\
\hline \multirow[t]{3}{*}{$\begin{array}{l}\text { Purposes of } \\
\text { mentoring }\end{array}$} & Article & $\begin{array}{l}\text { - } \\
\text { Academic preparation and development of } \\
\text { - } \quad \text { The development of scientific knowledge based on knowledge } \\
\text { built up by participants }[9,12,16,40] \\
\text { - To enhance the development personal capacities, skills and } \\
\text { abilities in students }[3,20,41,42] \\
\text { - Mentoring is a tool at to achieve academic } \\
\text { purposes }[4,9,12,16,40-42]\end{array}$ \\
\hline & Conference papers & $\begin{array}{l}\text { - To build, improve and develop future potential skills within } \\
\text { participants }[14,33-36]\end{array}$ \\
\hline & Book chapters & $\begin{array}{l}\text { - To build professional relationships between mentors and } \\
\text { mentees [37-39] }\end{array}$ \\
\hline \multirow{3}{*}{$\begin{array}{l}\text { Goals of } \\
\text { mentoring } \\
\text { programs }\end{array}$} & Article & $\begin{array}{l}\text { - To contribute to raising the quality of the mentoring process in } \\
\text { the academic field }[13,15,43]\end{array}$ \\
\hline & Conference papers & $\begin{array}{l}\text { - To foster positive mentor-student relationships through } \\
\text { communication }[14,34]\end{array}$ \\
\hline & Book chapters & $\begin{array}{l}\text { - To offer the mentees individualized support through of specific } \\
\text { tools }[38,39]\end{array}$ \\
\hline \multirow{3}{*}{ Terminology } & Article & - $\quad$ Mentor-mentee $[7-9,12,13,15,16,32,41,42,44]$ \\
\hline & Conference papers & - $\quad$ Mentor-mentee $[14,33-36]$ \\
\hline & Book chapters & - $\quad$ Mentor-student (teacher-student) [37-39] \\
\hline \multirow{3}{*}{$\begin{array}{l}\text { Future of } \\
\text { mentoring }\end{array}$} & Article & $\begin{array}{l}\text { - Identification and improvement of learning difficulties, thus } \\
\text { promoting good academic performance }[15,16,32,42] \text {. }\end{array}$ \\
\hline & Conference papers & $\begin{array}{l}\text { - Differentiates areas of student's development, offsite } \\
\text { internships }[14,33]\end{array}$ \\
\hline & Book chapters & $\begin{array}{l}\text { - Advice on the strategies-mostly cognitive-required for } \\
\text { succeed in a specific subject [37-39] }\end{array}$ \\
\hline
\end{tabular}

MQ4. What type of method is the most used for data analysis of e-mentoring programs in higher education?

We found that some articles are descriptive studies that were conducted using a survey technique and then analyzing the results by frequencies and percentages (Table 11). Most studies used an empirical-analytical approach [45] with quantitative analysis. To a lesser extent, some articles used surveys to ask about specific aspects such as mentoring, the use of social networks in research, and the degree of academic bias in mentoring programs. The quantitative approach had the following characteristics: for each document, the researcher performed some of the following steps:

- $\quad$ Posed a specific mentoring problem for each university $[7,20,32,36,39]$

- $\quad$ Reviewed what has been researched previously on e-mentoring $[7,8,20,32,46]$.

- Constructed a theoretical framework $[7,8,20,34,47]$

- Proposed Hypotheses. Tested the hypotheses through appropriate research designs $[7,8,20,34]$

On the other hand, the studies with qualitative analysis included a variety of conceptions, visions and techniques $[3,37]$ and the most relevant characteristics were:

- Some of the studies proposed a specific mentoring problem, but the researchers did not follow a clearly defined process $[3,38]$

- The approach taken by Rodrigues Reali et al. [37] was not as specific as in the quantitative approach reviewed $[7,20,39]$. These authors [37] used this approach to determine and improve 
the mentoring research questions for their investigation. They began by observing the virtual mentoring tendencies of different program types and their academic benefits.

- Data collection techniques were used such as observation [3,38], open interviews [3,37,42], document review [48], group discussion [3,38,48], among others.

Two articles applied mixed research methods, and two articles described specific tools used in e-mentoring programs and their benefits. One article explained the function and social significance of the e-mentoring process used in indigenous communities. Table 13. Shows a documentary analysis of the number of documents by analysis methodology used for the different authors.

Table 13. Number of documents by analysis methodology used. Source: created by the authors.

\begin{tabular}{lcl}
\hline Type of Study & No $^{\circ}$ Studies & \multicolumn{1}{c}{ Document } \\
\hline Quantitative & 16 & $\begin{array}{l}\text { DiRenzo et al., 2010; Venis, 2010; Murphy, 2011; Obura et al., 2011; Green } \\
\text { et al., 2012; Gunawardena et al., 2012; De Janasz, and Godshalk, 2013; Khan, } \\
\text { and Gogos, 2013; Nuankaew, and Temdee, 2014; Jacobs, et al., 2015; } \\
\text { Nuankaew, and Temdee, 2015; Doyle et al., 2016; Tominaga, and Kogo, 2018; } \\
\text { Farheen, J., and Dixit, 2018; Doukakis et al., 2019; Briscoe, 2019. }\end{array}$ \\
Qualitative & 5 & $\begin{array}{l}\text { Stewart, and Carpenter, 2009; Rodrigues Reali et al., 2010; Butler et al., 2013; } \\
\text { Greindl et al., 2013; Kahraman, and Abdullah, 2016. }\end{array}$ \\
Mix Methods & 9 & $\begin{array}{l}\text { Golubski, 2011, Williams, and Kim, 2011; Risquez, and Sánchez-García, 2012; } \\
\text { Drouin et al., 2015; Owen, 2015; ChanLin, 2016; Trainer et al., 2017; } \\
\text { Tinoco-Giraldo et al., 2018; Haran, and Jeyaraj, 2019. } \\
\text { Ligadu, and Anthony, 2015; Owen et al., 2018; Singh, and Kumar, 2019. }\end{array}$ \\
$\begin{array}{l}\text { Additional } \\
\text { Research }\end{array}$ & 3 &
\end{tabular}

\subsection{SLR Results}

RQ1. What areas are being developed with the application of an e-mentoring program in higher education?

There are three areas in which a e-mentoring program is effectively developed in the literature. The first area is learning and development. For example, Murphy [7] and Jacobs et al. [43] tried to bring the participants of their mentoring programs closer to their own professional reality through the process of analysis. Furthermore, as an expert in the mentee's discipline of study, mentors helped provide solutions for the mentees' academic problems.

According to Risquez and Sánchez-García [49], mentoring is a tool that contributes to the development of personal and professional growth strategies for participants. Therefore, the role of the mentor is to train mentees through multiple tools so that they become better observers of themselves and their relationships [32].

Tominaga and Kogo [20] outline the development of a set of professional skills and competencies and clarify how virtual mentoring programs in higher education institutions can contribute to the integral formation of the participants, generate effective gains, enhance the capacities and strengthen the weaknesses of participants, and guide participants in the effective and adequate use of academic opportunities.

The second area is the contribution to the internal processes of higher education institutions in such a way that mentoring programs adapt to current educational trends. Haran and Jeyaraj [16] and Doukakis et al. [33] believe the choice of adequate information from e-mentoring projects should effectively fit it into institutional policies for future processes. Similarly, Rodrigues Reali et al. [37] and Kahraman and Abdullah [50] stablished a link between cultural and structural continuity of mentoring programs to achieve specific objectives.

The third area is educational methodology to promote continuous improvement of the teachinglearning approach. This finding is congruent with the work of ChanLin [13] and Briscoe [9], which highlighted the benefits of effective mentoring that promote a global understanding of situations at the 
educational level and foster a culture of leadership and entrepreneurship based on the development of networks in the mentoring programs.

RQ2. What are the characteristics of e-mentoring programs in higher education?

Table 14 summarizes the characteristics found for higher education e-mentoring programs.

According to Venis [39], virtual mentoring involves communication and interaction processes on the part of the participants and personalized attention to mentees based on their problems, needs, and specific interests.

Green et al. [47] and Drouin et al. [44] suggest that the main purpose of an e-mentoring program is to "serve as a place for the exchange of ideas, proposals, and experiences," allowing for sharing of materials, proposing working groups, and facilitating the creation of an intranet that enables communication between the agents of each mentoring program. To improve the performance of health professionals, Doyle et al. [46] proposes that mentoring should be mutually beneficial. For example, the development of occupational therapy students' capacities will benefit from the exchange of knowledge and the relationships they establish with their mentors. Nuankaew and Temdee [51] describe an example of how a virtual mentoring program was applied to four universities in Thailand with a personalized opportunity to address individual learning needs of the mentees. This program helped 205 mentees develop new skills and knowledge and to improve, enrich, and broaden their professional and personal perspectives. Singh and Kumar [40] attest that mentoring programs help learners with "building confidence in handling challenges and problems." In a similar vein, Tinoco-Giraldo et al. [14] found that e-mentoring programs "help with advice on professional development and personal growth, as well as networking opportunities."

On the other hand, De Janasz and Godshalk [4] describe an online mentoring intervention for Pennsylvania University students, which consisted of close, systematic, and permanent accompaniment of the mentee, which helped support and facilitate the process of construction of learning of various types: cognitive, affective, socio-cultural, and existential.

Table 14. Characteristics of e-mentoring programs in higher education. Source: created by the authors.

\begin{tabular}{|c|c|}
\hline Features Found in the Mentoring Programs & Titles of the Papers \\
\hline It involves personalized attention to mentees & $\begin{array}{l}\text { E-mentoring the individual writer within a global } \\
\text { creative community (2010). }\end{array}$ \\
\hline $\begin{array}{l}\text { Serve as a place for the exchange of ideas, } \\
\text { proposals and experiences }\end{array}$ & $\begin{array}{l}\text { Implementing an industrial mentoring program to } \\
\text { enhance student motivation and retention (2012), Using } \\
\text { methodological triangulation to examine the effectiveness } \\
\text { of a mentoring program for online instructors (2015). }\end{array}$ \\
\hline Mutually beneficial & $\begin{array}{l}\text { Faculty mentors' perspectives on e-mentoring } \\
\text { post-professional occupational therapy doctoral } \\
\text { students (2016). }\end{array}$ \\
\hline Address individual learning needs of the mentees & $\begin{array}{l}\text { Determining of compatible different attributes for online } \\
\text { mentoring model (2014). }\end{array}$ \\
\hline $\begin{array}{l}\text { Building confidence in handling challenges } \\
\text { and problems }\end{array}$ & $\begin{array}{l}\text { E-mentoring alternative paradigm for entrepreneurial } \\
\text { aptitude development (2019). }\end{array}$ \\
\hline $\begin{array}{l}\text { Help with advice on professional development } \\
\text { and personal growth, as well as networking } \\
\text { opportunities. }\end{array}$ & $\begin{array}{l}\text { Utilizing technological ecosystems to support graduate } \\
\text { students in their practicum experiences (2018). }\end{array}$ \\
\hline $\begin{array}{l}\text { Support and facilitate the process of construction } \\
\text { of learning of various types }\end{array}$ & $\begin{array}{l}\text { The role of e-mentoring in protégés' learning and } \\
\text { satisfaction (2013). }\end{array}$ \\
\hline $\begin{array}{l}\text { Stimulates people's professional potential based } \\
\text { on the transmission of knowledge and learning } \\
\text { through experience. }\end{array}$ & $\begin{array}{l}\text { Electronic mentoring: An innovative approach to } \\
\text { providing clinical support (2009). }\end{array}$ \\
\hline $\begin{array}{l}\text { Motivate and provoke changes in their values, } \\
\text { attitudes and skills }\end{array}$ & $\begin{array}{l}\text { Social impact in personalised virtual professional } \\
\text { development pathways (2018). }\end{array}$ \\
\hline
\end{tabular}


Finally, Stewart and Carpenter [3], considers that the mentoring process stimulates people's professional potential based on the transmission of knowledge and learning through experience. In other words, e-mentoring seeks to turn capabilities into competencies and skills. Owen [52] went ever further and claimed that mentoring promotes change, improvement, and growth of the individual or the beneficiaries "by motivating and provoking changes in their values, attitudes, and skills." Therefore, this process was highly recommended in her approach with indigenous communities in New Zealand.

RQ3. How are e-mentoring programs in higher education evaluated?

Evaluation of e-mentoring programs is developed according to the organization and takes into account the functions that are applied as a mentoring strategy by the participants [53].

Rodrigues Reali et al. [37] describe periodic evaluations via interviews to evaluate their performance at different stages of the process. These interviews give the opportunity for the mentor and mentee to discuss progress on the objectives set at the beginning of the mentoring program. ChanLin [13] believes periodic interviews are the best way to collect and match information and provide an opportunity to reevaluate the mentoring approach and generate discussion about the progress.

DiRenzo et al. [32] designed a self-evaluation survey regarding interaction between mentees and mentors in a physical therapy program; all of these constitute advances with respect to the measurement of various personal and contextual variables. They used a goal achievement scale, which allowed the mentees and mentors to develop accurate and level descriptions of the progress of the skills acquired in the e-mentoring program.

To guarantee the effectiveness of the evaluation process of the e-mentoring program at the University of Urbana-Champaign, Haran and Jeyaraj [16] designed an evaluation process distributed into four phases: the evaluation plan, evidence collection, synthesis, and the report and diffusion.

The results obtained by Ligadu and Anthony [15] determined that an e-mentoring tool designed for the program (MentorTokou) was the best resource to allow electronic collection, management, and presentation.

On the other hand, whereas the above authors focused on individual processes created for evaluation, Khan and Gogos [41] used an $180^{\circ}$ performance appraisal, where the mentees were evaluated by their mentors, peers, and (eventually) external agents, such biotechnology lab practitioners. The evaluators were chosen by the mentor, and the mentor informed the evaluators of the objectives set out in the mentee's action plan. By implementing this evaluation method, the information obtained became more substantial [48].

Continuing with program evaluation, Obura et al. [8] used five different methods to evaluate the e-mentoring program pilot established at Aga Khan University Postgraduate Medical Education Program in Kenya. First, a community event for participants was virtually launched, and observations were derived from the event records. Second, after each mentoring session, participants provided extra information by completing an online survey using WebEx conferences. Third, participants, responded to a survey about their perceptions of the mentoring sessions and WebEx experiences using a Likert-like scale. Fourth, a semi-structured telephone interview allowed them to capture complaints and exchange stories about the mentoring process. Finally, the faculty supporting the program were interviewed to express their perceptions.

Similarly, with regard to the evaluations, Tinoco-Giraldo et al. [14] used the Kirkpatrick model of training evaluation [54] to assess their program. The evaluation measures how the participants react to the mentoring, with respect to the process they have just received, in the same way, learning is evaluated establish specific objectives. One way to measure this level is to evaluate the knowledge, skills and attitudes of the participants before and after the course. This involves checking if there has been a change in behavior that is necessary, which requires evaluation through interviews with participants and coordinator members of the mentoring program. Finally, it also includes an evaluation after the process is concluded.

De Janasz and Godshalk [4], Farheen and Dixit [34] and Butler et al. [42] used self-evaluation to analyze his/her own performance according to previously established indicators or parameters and the 
evaluator to critically assess his/her own performance and strengths and weaknesses, providing useful information for the final evaluation of results of the program.

RQ4. What are the indicators of effectiveness of e-mentoring programs in higher education?

In this regard, Harris and Lee [55] state that, in higher education, teachers have a responsibility to develop the social skills of students by posing and carrying out a series of specific activities expecting concrete and effectiveness results through the use of measurable indicators.

In addition, Williams and Kim [11], support the notion that the educational process has been linked, thus generating processes oriented to form the subject in a wide way, with aptitudes for the application of organizational processes, with quality, to be inserted to the society generator of organizations that offer the possibility of new companies or businesses. They indicate that the outcome indicators of the mentoring project completion provided by all of the mentees, the mentor retention, the extension of the program into a next semester, and the intention to complete the mentoring program within other Master's programs at Midwestern U.S. Universities is a big indicator of effectiveness and success.

Tinoco-Giraldo et al. [14] and Singh and Kumar [40], have noted that the application of a mentoring program can have an impact on the development of professional competencies. However, while the former observed that impact of good strategies, professional mentors and extensive support for the coordination of the mentoring program, makes the e-mentoring program effective; the latter observed that showing interest and motivation towards the program content are aspects that have a positive influence on the success of a virtual mentoring program.

In order to determine how e-mentoring in higher education can be effective against school failure, Greindl et al. [48] recognized that e-mentoring has the capacity to cover different spheres of influence: environment, family, and individual factors. They concluded that e-mentoring must be organized according to continuous processes, developed in an active and dynamic way, and planned from an interdisciplinary point of view. Within this framework, Doukakis et al. [33] claims that establishing an institutional e-mentoring program could have a positive effect on the resolution of situations in which the mentees do not achieve the objectives.

Within this context, Kahraman and Abdullah [50] proposed that students of the Department of Computer Education and Instructional Technologies of Anadolu University in Turkey contribute to the internal processes of the institution in such a way that the e-mentoring program found and adjusted possibilities of adaptation to the educational trends of the time.

The e-mentoring program takes on a special importance, as shown by the findings of Trainer et al. [35], which state that mentoring should be used in higher education institutions to contribute to the integral formation of students, to generate effective gains in the learning of disciplines, and to strengthen students' capacities.

\section{Conclusions and Future Research}

Only a few authors to date $[8,9,20,32,36,42,44]$ have included challenges and opportunities in e-mentoring as part of their research. Their work often adapts the extensive literature on computer-mediated mentoring to compensate for the lack of research in the field. However, e-mentoring itself has not receive extensive attention, and it is often compared to face-to-face mentoring with the implicit assumption that it is a poor alternative to the traditional model.

During the literature review, the absence or incompleteness of research was identified by the authors. Examples of this included: conceptual confusion $[7,13,49]$ disagreements on operational definitions [46,48,51], methodological weaknesses [20], and lack of evidence of the characteristics and qualities of an effective e-mentoring process $[11,14]$. A contrast of the drawbacks identified by the authors in the SLR is shown in Table 15. 
Table 15. Lack of research on e-mentoring.

\begin{tabular}{cl}
\hline & \multicolumn{1}{c}{ Absence or Incompleteness of Research } \\
\hline $\begin{array}{c}\text { Conceptual } \\
\text { confusion }\end{array}$ & $\begin{array}{l}\text { Confusion in the definitions, both of e-mentoring and of the roles, functions, and } \\
\text { activities of mentors [13]. There are authors who question this clarity and there are } \\
\text { those who do not notice this deficiency and argue their proposals amidst the confusion } \\
\text { of terms. According to Risquez, and Sánchez-García [49] there is a lack of a precise } \\
\text { definition of e-mentoring, which in some cases, causes confusion as it has a different } \\
\text { meaning in the higher education field. }\end{array}$ \\
\hline $\begin{array}{c}\text { Disagreements on } \\
\text { operational } \\
\text { definitions }\end{array}$ & $\begin{array}{l}\text { Lack of precision in the operational definition of e-mentoring in the higher education } \\
\text { field, due to the scope of the investigations [51] or because of other particular fields } \\
\text { where it occurs [46]. Not having clear concepts and agreed operational definitions at } \\
\text { least in each field where e-mentoring takes place can limit the understanding and } \\
\text { usefulness of empirical research [48]. }\end{array}$ \\
\hline $\begin{array}{c}\text { Methodological } \\
\text { weaknesses }\end{array}$ & $\begin{array}{l}\text { Most of the reports reviewed did not acknowledge the development of specific models } \\
\text { for e-mentoring in higher education and there was no clear information on the } \\
\text { validation of instruments that assess the factors involved with e-mentoring [20]. }\end{array}$ \\
\hline $\begin{array}{c}\text { Lack of evidence of } \\
\text { the characteristics } \\
\text { and qualities of an } \\
\text { effective }\end{array}$ & $\begin{array}{l}\text { Tinoco-Giraldo et al. [14] note that extensive work has been done on mentoring over } \\
\text { the last two decades. Such research and models focus on the business field and to a } \\
\text { lesser extent on the academic field. However, little research addresses the qualities and } \\
\text { characteristics of an effective mentor, minimal research investigates the characteristics } \\
\text { and qualities of good mentoring [11], and no research in mentoring applied for } \\
\text { students in offsite internships [14]. }\end{array}$ \\
\hline
\end{tabular}

This SLR is based on the position that e-mentoring is a different technique that should be investigated in its particular context and not compared to in-person mentoring. There is a significant demand in the education field for sharing techniques or methods to develop the potential of students. Current research on e-mentoring has been guided to support aspects such as the phases and criteria for completing the mentoring process, personal development outcomes, the quality of relationships, and the choice of mentor and mentees.

Likewise, the analysis identified some key areas that need to be addressed. First was the need to define the profile of the mentor. Tominaga and Kogo [20] outlined several concepts such as promoting the exchange of teaching-learning experiences and practices to prepare future mentees to participate in future versions of mentoring programs. In the same way, Argente-Linares et al. [56] specify that providing teaching-learning criteria to identify the best strategies can capitalize on e-mentoring in higher education. One resource that is overlooked is new graduates, who have not been considered for alternative support from the university as e-mentoring programs based on the research we conducted. The social service team of the university and the professional practices should focus on supporting mentees and facilitating a career path where the mentee can acquire practical experience.

Future research is needed to evaluate e-mentoring programs that incorporate the principles of effective mentoring programs outlined by Obura et al. [8], Golubski [38], Briscoe [9], and Doukakis et al. [33]: (1) a clear program management structure, (2) a mentoring-matching process that is well designed, (3) initial training and preparation for mentors and mentees to participate in mentoring, (4) ongoing support programs for mentors and mentees, and (5) periodic review for continuous quality improvement of the program.

Future research should also focus on the sustainable development of offsite internships groups. As Tinoco-Giraldo et al. [14] suggest, future explorations of e-mentoring programs should focus on academic and practical issues and social responsibility. To achieve a level of success similar to some of the studies outlined in this review, the development of virtual mentoring programs for students conducting offsite internships, needs to follow structural, logistical, and pragmatic aspects related to mentoring practices.

The structural aspects refer to the theoretical, critical, and reflective foundations on which the program will be based. Logistical issues refer to the operational part to implement e-mentoring process, 
that is, the basic infrastructure and organization, which implies its implementation as sensitive and adaptive to offsite internships. Finally, the pragmatic aspects are related to the implementation of mentoring, where the human factor becomes a vital piece, while it is the educational community (authorities, teachers, mentors, mentees) who will give meaning to the mentoring task.

Therefore, it is appropriate to negotiate meanings and beliefs about what is thought to be the mentoring process in order to direct efforts to a common plan. It is also a key point to emphasize developing students' capacities, skills, values, and attitudes through the mentoring process and the learning experiences that are incorporated into their practicum. Mentoring not only benefits the students but also the employers or mentors, who develop leadership skills. Based on this premise, the implementation of e-mentoring in higher education institutions requires that educational leaders: be willing to assume the role of mentor to advise both teachers and students, be trained to serve as mentors, invest in their own training, work on linking students and teachers with other leaders who could play the role of mentors in institutional projects, be integrated into the development of mentoring to provide a managerial and global vision, write about the success e-mentoring stories to generate a database to guide other participants, and assume the social responsibility that comes with the integral formation of an individual through e-mentoring.

Finally, we highlight the need for more research on mentoring experiences in higher education to encourage the implementation of other new experiences, thus overcoming some of the main difficulties detected in the development of mentoring in higher education institutions.

At this time, it is essential to share research results and methods between institutions, recognizing the relative importance of research existing in different contexts. The need to form a community of practice on the subject to compensate for the lack of literature is imperative and should be directed at generating a discussion that encompasses diversity among institutions.

Author Contributions: Conceptualization, H.T.-G., and E.M.T.S.; Investigation, H.T.-G.; Methodology, H.T.-G., E.M.T.S. and F.J.G.-P.; validation, H.T.-G., E.M.T.S. and F.J.G.-P.; formal analysis, H.T.-G., and E.M.T.S.; Writing—original draft preparation, H.T.-G.; Writing—review and editing, H.T.-G., E.M.T.S. and F.J.G.-P. All authors have read and agreed to the published version of the manuscript.

Funding: This work has been partially funded by the Spanish Government Ministry of Economy and Competitiveness throughout the DEFINES project (Ref. TIN2016-80172-R).

Acknowledgments: This work is carried out in the Doctorate Programme Formación en la Sociedad del Conocimiento de la Universidad de Salamanca [57,58]. The program is regulated by the Real Decreto 99/2011 [59].

Conflicts of Interest: The authors declare no conflict of interest. The funders had no role in the design of the study; in the collection, analyses, or interpretation of data; in the writing of the manuscript, or in the decision to publish the results.

\section{References}

1. UNESCO. Marco de Competencias de los Docentes en Materia de TIC UNESCO_UNESCO Digital Library. Available online: https://unesdoc.unesco.org/ark:/48223/pf0000371024 (accessed on 24 March 2020).

2. Headlam-Wells, J.; Gosland, J.; Craig, J. “There's magic in the web": E-Mentoring for women's career development. Career Dev. Int. 2005, 10, 444-459. [CrossRef]

3. Stewart, S.; Carpenter, C. Electronic mentoring: An innovative approach to providing clinical support. Int. J. Ther. Rehabil. 2009, 16, 199-206. [CrossRef]

4. De Janasz, S.C.; Godshalk, M.V. The role of e-mentoring in protégés'. Learning and satisfaction. Group Org. Manag. 2013, 38, 743-774. [CrossRef]

5. Neely, A.R.; Cotton, J.; Neely, A.D. E-mentoring: A model and review of the literature. AIS Trans. Hum.-Comput. Interact. 2017, 9, 220-242. Available online: https://aisel.aisnet.org/thci/vol9/iss3/3 (accessed on 24 March 2020). [CrossRef]

6. Crisp, G. Promising practices and programs: Current efforts and future directions. New Dir. Commun. Coll. 2016, 2016, 103-110. [CrossRef]

7. Murphy, W.M. From E-mentoring to blended mentoring: Increasing students' developmental initiation and mentors' satisfaction. Acad. Manag. Learn. Educ. 2011, 10, 606-622. [CrossRef] 
8. Obura, T.; Brant, W.E.; Miller, F.; Parboosingh, I.J. Participating in a community of learners enhances resident perceptions of learning in an e-mentoring program: Proof of concept. BMC Med. Educ. 2011, 11, 3. [CrossRef] [PubMed]

9. Briscoe, P. Virtual mentor partnerships between practicing and preservice teachers. Int. J. Mentor. Coach. Educ. 2019, 8, 235-254. [CrossRef]

10. Camilleri, F. Towards the study of actor training in an age of globalised digital technology. Theatr. Dance Perform. Train. 2015, 6, 16-29. [CrossRef]

11. Williams, S.L.; Kim, J. E-mentoring in online course projects: Description of an e-mentoring scheme. Int. J. Evid. Based Coach. Mentor. 2011, 9, 80-95. Available online: http://ijebcm.brookes.ac.uk/documents/ vol09issue2-paper-06.pdf (accessed on 28 February 2020).

12. Owen, H.; Whalley, R.; Dunmill, M.; Eccles, H. Social impact in personalised virtual professional development pathways. J. Educators Online 2018, 15, 1-11. Available online: https://files.eric.ed.gov/fulltext/EJ1168953.pdf (accessed on 28 February 2020). [CrossRef]

13. ChanLin, L.J. Students' involvement and community support for service engagement in online tutoring. J. Educ. Med. Libr. Sci. 2016, 53, 245-268. [CrossRef]

14. Tinoco-Giraldo, H.; Torrecilla Sánchez, E.M.; García-Peñalvo, F.J. Utilizing technological ecosystems to support graduate students in their practicum experiences. In TEEM'18 Doctoral Consortium, Proceedings of the TEEM'18: Sixth International Conference on Technological Ecosystems for Enhancing Multiculturality, Salamanca, Spain, 24-26 October 2018; García Peñalvo, F.J., Ed.; ACM: New York, NY, USA, 2018; pp. 1004-1009. [CrossRef]

15. Ligadu, C.; Anthony, P. E-mentoring 'MentorTokou': Support for mentors and mentees during the practicum. Procedia Soc. Behav. Sci. 2015, 186, 410-415. [CrossRef]

16. Haran, V.V.; Jeyaraj, A. Organizational e-mentoring and learning: An exploratory study. IRMJ 2019, 32, 58-72. [CrossRef]

17. Zabalza, M.A. El prácticum y las prácticas externas en la formación universitaria. Revista Prácticum 2017, 1, 1-23. Available online: https://revistapracticum.com/index.php/iop/article/view/15/42 (accessed on 21 February 2020).

18. Mareque, M.; De Prada, E. Evaluación de las competencias profesionales a través de las prácticas externas: Incidencia de la creatividad. Revista de Investigación Educativa 2018, 36, 203-219. [CrossRef]

19. De Janasz, S.C.; Ensher, E.A.; Heun, C. Virtual relationships and real benefits: Using e-mentoring to connect business students with practicing managers. Mentor. Tutoring Partnersh. Learn. 2008, 16, 394-411. [CrossRef]

20. Tominaga, A.; Kogo, C. Attributes of good e-learning mentors according to learners. Univ. J. Educ. Res. 2018, 6, 1777-1783. [CrossRef]

21. Weinberg, F.J.; Locander, W.B. Advancing Workplace spiritual development: A dyadic mentoring approach. Leadersh. Q. 2014, 25, 391-408. [CrossRef]

22. Vidal Ledo, M.; Oramas Díaz, J.; Borroto Cruz, R. Revisiones sistemáticas. Educación Médica Superior 2015, 29, 198-207. Available online: http://scielo.sld.cu/pdf/ems/v29n1/ems19115.pdf (accessed on 25 February 2020).

23. Ramírez-Montoya, M.S.; García-Peñalvo, F.J. Co-Creación e innovación abierta: Revisión sistemática de literatura. Comunicar 2018, 54, 9-18. [CrossRef]

24. García-Peñalvo, F.J. Revisiones y mapeos sistemáticos de literatura. In Recursos Docentes de la Asignatura Procesos y Métodos de Modelado Para la Ingeniería web y web Semántica; Procesos y métodos de modelado para la ingeniería web y web semántica. Curso 2018-2019. Recursos de la asignatura procesos y métodos de modelado para la ingeniería web y web semántica del máster universitario en sistemas inteligentes de la Universidad de Salamanca; Grupo GRIAL, Universidad de Salamanca: Salamanca, España, 2019.

25. UNESCO. (2019, October 14). Thesaurus: Mentoring. Available online: http://vocabularies.unesco. org/browser/thesaurus/en/page/?uri=http://vocabularies.unesco.org/thesaurus/concept17109 (accessed on 24 March 2020).

26. UNESCO. (2006, May 23). Thesaurus: Higher Education. Available online: http://vocabularies.unesco. org/browser/thesaurus/en/page/?uri=http://vocabularies.unesco.org/thesaurus/concept1485 (accessed on 24 March 2020).

27. UNESCO. (2006, May 23). Thesaurus: Internships. Available online: http://vocabularies.unesco.org/browser/ thesaurus/en/page/concept2577 (accessed on 24 March 2020).

28. Zhu, J.; Liu, F.; Liu, W. The Secrets behind Web of Science's DOI Search. Scientometrics 2019, 119, $1745-1753$. [CrossRef] 
29. Aguilera Eguía, R. ¿Revisión sistemática, revisión narrativa o meta-análisis? Revista de la Sociedad Española del Dolor 2014, 21, 359-360. [CrossRef]

30. Moher, D.; Liberati, A.; Tetzlaff, J.; Altman, D.G. Preferred reporting items for systematic reviews and meta-analyses: The PRISMA statement. Ann. Intern. Med. 2009, 151, 264-269. [CrossRef] [PubMed]

31. Bullington, J.S.; Boylston, S.D. Strengthening the Profession, Assuring Our Future: ACRL's New Member Mentoring Program Pairs Library Leaders with New Professionals. Coll. Res. Libr. News 2010, 62, 430-452. Available online: https://crln.acrl.org/index.php/crlnews/article/view/20883/25660 (accessed on 19 March 2020). [CrossRef]

32. DiRenzo, M.S.; Linnehan, F.; Shao, P.; Rosenberg, W.L. A moderated mediation model of e-mentoring. J. Vocat. Behav. 2010, 76, 292-305. [CrossRef]

33. Doukakis, S.; Koutidou, E.; Aspasia, A. Designing an E-Mentoring Program for Supporting Teachers' Training. In Proceedings of the 4th South-East Europe Design Automation, Computer Engineering, Piraeus, Greece, 20-22 September 2019. [CrossRef]

34. Farheen, J.; Dixit, S. E-mentoring system application. In IoT in Social, Mobile, Analytics and Cloud; IEEE: Palladam, India, 2018. [CrossRef]

35. Trainer, E.H.; Kalyanasundaram, A.; Herbsleb, J.D. E-mentoring for software engineering: A socio-technical perspective. In Proceedings of the 2017 IEEE/ACM 39th International Conference on Software Engineering: Software Engineering Education and Training Track (ICSE-SEET), Buenos Aires, Argentina, 20-28 May 2017. [CrossRef]

36. Gunawardena, C.N.; Jayatilleke, B.G.; Fernando, S.; Kulasekere, C.; Lamontagne, M.D.; Ekanayake, M.B.; Thaiyamuthu, T. Developing Online Tutors and Mentors in Sri Lanka through a Community Building Model: Predictors of Satisfaction; IEEE: Colombo, Sri Lanka, 2012. [CrossRef]

37. Rodrigues Reali, A.; Simões Tancredi, R.; Nicoletti Mizukami, M. Professional knowledge of teaching and the online mentoring program: A case study in the brazilian educational context. In the Wiley International Handbook of Mentoring; Wiley \& Sons, Inc.: Medford, MA, USA, 2010; Volume 5, pp. 261-278.

38. Golubski, P.M. Utilizing virtual environments for the creation and management of an e-mentoring initiative. In Pedagogical and Andragogical Teaching and Learning with Information Communication Technologies; IG Global: Pittsburgh, PA, USA, 2012; pp. 73-87.

39. Venis, L. E-Mentoring the Individual Writer within a Global Creative Community. Available online: www.igi-global.com/chapter/mentoring-individual-writer-within-global/38028 (accessed on 4 May 2020). [CrossRef]

40. Singh, P.; Kumar, K. E-mentoring Alternative Paradigm for Entrepreneurial Aptitude Development. Acad. of Entrep. J. 2019, 25, 1-12. Available online: https://www.abacademies.org/articles/ementoring-alternativeparadigm-for-entrepreneurial-aptitude-development-8067.html (accessed on 28 February 2020).

41. Khan, R.; Gogos, A. Online Mentoring for biotechnology graduate students: An industry-academia partnership. J. Asynchronous Learn. Netw. 2013, 17, 89-107. [CrossRef]

42. Butler, A.J.; Whiteman, R.S.; Crow, G.M. Technology's role in fostering transformational educator mentoring. Int. J. Mentor. Coach. Educ. 2013, 2, 233-248. [CrossRef]

43. Jacobs, K.; Doyle, N.; Ryan, C. The Nature, perception, and impact of e-mentoring on post-professional occupational therapy doctoral students. Occup. Ther. Health Care 2015, 29, 201-213. [CrossRef]

44. Drouin, M.; Stewart, J.; Van Gorder, K. Using methodological triangulation to examine the effectiveness of a mentoring program for online instructors. Distance Educ. 2015, 36, 400-418. [CrossRef]

45. Valenzuela-González, J.R. Mixed methods: Lessons learned from five cases of doctoral theses. In TEEM'19 Implementation of Qualitative and Mix Methods Researches, Proceedings of the TEEM'19: Seventh International Conference on Technological Ecosystems for Enhancing Multiculturality, León, Spain, 16-18 October 2019; Conde González, M., Rodríguez Sedano, F.J., Fernández Llamas, C., García Peñalvo, F.J., Eds.; ACM: New York, NY, USA, 2019; pp. 525-529. [CrossRef]

46. Doyle, N.; Jacobs, K.; Ryan, C. Faculty mentors' perspectives on e-mentoring post-professional occupational therapy doctoral students. Occup. Ther. Int. 2016, 23, 305-317. [CrossRef] [PubMed]

47. Green, M.G.; Niemi, A.D.; Roudkovski, M. Implementing an industrial mentoring program to enhance student motivation and retention. In Corporate Member Council Industry Speaker \& Best Paper Recognition; ASEE: San Antonio, TX, USA, 2012. 
48. Greindl, T.; Schirner, S.; Albert Ziegler, H.S. The Effectiveness of a One-Year Web-Based Mentoring Program for Girls in Stem. Web Based Communities and Social Media; Elsevier: Prague, Czech Republic, 2013; Volume 69, pp. 408-418.

49. Risquez, A.; Sánchez-García, M. The jury is still out: Psychoemotional support in peer e-mentoring for transition to university. Internet High. Educ. 2012, 15, 213-221. [CrossRef]

50. Kahraman, M.; Abdullah, K. E-mentoring for professional development of pre-service teachers: A case study. Turkish Online J. Distance Educ. 2016, 17, 76-89. [CrossRef]

51. Nuankaew, P.; Temdee, P. Determining of compatible different attributes for online mentoring model. In Information Theory and Aerospace E Electronics Systems (VITAE); IEEE: Aalborg, Denmark, 2014. [CrossRef]

52. Owen, H. Making the Most of mobility: Virtual mentoring and education practitioner professional development. Res. Learn. Technol. 2015, 23,1-14. [CrossRef]

53. Torrecilla Sánchez, E.M.; Rodríguez Conde, M.J.; Herrera García, M.E.; Martín Izard, J.F. Evaluación de Calidad de un Proceso de Tutoría de Titulación Universitaria: La Perspectiva del Estudiante de Nuevo Ingreso en Educación. Revista Española de Orientación y Psicopedagogía 2013, 24, 79-99. Available online: https://www.redalyc.org/pdf/3382/338230794006.pdf (accessed on 28 February 2020). [CrossRef]

54. Kirkpatrick, D.; Kirkpatrick, J. Evaluating Training Programs: The Four Levels, 3rd ed.; Berrett-Koehler Publishers: Oakland, CA, USA, 2006.

55. Harris, T.M.; Lee, C.N. Advocate-mentoring: A communicative response to diversity in higher education. Commun. Educ. 2019, 68, 103-113. [CrossRef]

56. Argente-Linares, E.; Pérez-López, M.; Ordóñez-Solana, C. Practical experience of blended mentoring in higher education. Mentor. Tutoring Partnersh. Learn. 2016, 24, 399-414. [CrossRef]

57. García-Peñalvo, F.J. Education in Knowledge Society: A new PhD Programme approach. In Proceedings of the First International Conference on Technological Ecosystems for Enhancing Multiculturality (TEEM'13), Salamanca, Spain, 14-15 November 2013; García-Peñalvo, F.J., Ed.; Association for Computing Machinery: New York, NY, USA, 2013; pp. 575-577. [CrossRef]

58. García-Peñalvo, F.J. Formación en la sociedad del conocimiento, un programa de doctorado con una perspectiva interdisciplinar. Educ. Knowl. Soc. 2014, 15, 4-9.

59. Gobierno de España. Real Decreto 99/2011, de 28 de Enero, por el que se Regulan las Enseñanzas Oficiales de Doctorado. In Ministerio de Educación; Gobierno de España, 2011; pp. 13909-13926. Available online: https://goo.gl/imEsz6 (accessed on 20 May 2020).

(C) 2020 by the authors. Licensee MDPI, Basel, Switzerland. This article is an open access article distributed under the terms and conditions of the Creative Commons Attribution (CC BY) license (http://creativecommons.org/licenses/by/4.0/). 